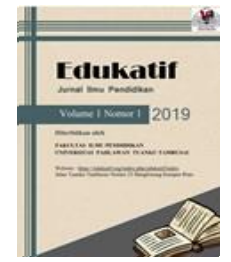

\title{
Pengembangan Media Komik Elektronik untuk Mengurangi Bullying pada Siswa Anak Usia Dini
}

\author{
Rezza Amalia $^{1 凶}$, Benny Hendriana $^{2}$, Amelia Vinayastri $^{3}$ \\ Universitas Muhammadiyah Prof. Dr. Hamka, Indonesia ${ }^{1,2,3}$ \\ E-mail : rezzaaam@gmail.com ${ }^{1}$, benny_hendriana@uhamka.ac.id ${ }^{2}, \underline{\text { amelia vinayastri@ uhamka.ac.id }^{3}}$
}

\begin{abstract}
Abstrak
Tujuan dari penelitian ini adalah untuk mengembangkan media pembelajaran komik elektronik edukasi bullying untuk siswa kelompok B di PAUD Anggrek Tanjung barat guna mengurangi bullying pada lingkungan anak. Jenis metode yang digunakan peneliti adalah $\mathrm{R} \& \mathrm{D}$ (Research and Development) dengan model pengembangan ADDIE. Uji validitas dinilai berdasarkan dari ahli media, ahli materi, ahli bahasa, guru PAUD Anggrek, dan 12 orang tua siswa kelompok B PAUD Anggrek Tanjung Barat. Hasil presentase ahli media sebesar $85 \%$ dengan kategori valid, presentase ahli materi sebesar $91 \%$ dengan kategori sangat valid, dan presentase ahli bahasa sebesar 75\% dengan kategori valid. Hasil uji coba terhadapat guru PAUD Anggrek sebesar $89 \%$ dengan kategori sangat valid dan 12 orang tua siswa kelompok B PAUD Anggrek sebesar presentase 93\% dengan kategori sangat valid. Dari hasil tersebut, maka dapat disimpulkan bahwa komik elektronik untuk edukasi bullying pada anak usia dini valid dan layak digunakan dalam pembelajaran siswa di PAUD Anggrek Tanjung Barat.
\end{abstract}

Kata Kunci: Anak Usia Dini, Komik Elektroni, Perlindungan Anak, Perundungan

\section{Abstract}

The purpose of this study was to develop learning media for bullying electronic comics for group B students at PAUD Anggrek Tanjung Barat in order to reduce bullying in the child's environment. The type of method used by the researcher is $R \& D$ (Research and Development) with the ADDIE development model. The validity test was assessed based on media experts, material experts, linguists, Anggrek PAUD teachers, and 12 parents of group B Anggrek PAUD Tanjung Barat students. The results of the percentage of media experts are $85 \%$ in the valid category, the percentage of material experts is $91 \%$ in the very valid category, and the percentage of linguists is $75 \%$ in the valid category. The results of the trial on Anggrek PAUD teachers were $89 \%$ in the very valid category and 12 parents of group B Anggrek PAUD students with a percentage of $93 \%$ in the very valid category. From these results, it can be concluded that electronic comics for bullying education in early childhood are valid and suitable for use in student learning at PAUD Anggrek Tanjung Barat.

Keywords: Bullying, Child Protection, Early Childhood, Electronic Comics

Copyright (c) 2021 Rezza Amalia, Benny Hendriana, Amelia Vinayastri

$\triangle$ Corresponding author:

Email : rezzaaam@gmail.com

DOI $\quad$ https://doi.org/10.31004/edukatif.v3i5.869

ISSN 2656-8063 (Media Cetak)

ISSN 2656-8071 (Media Online)

Edukatif : Jurnal Ilmu Pendidikan Vol 3 No 5 Tahun 2021 p-ISSN 2656-8063 e-ISSN 2656-8071 
2393 Pengembangan Media Komik Elektronik untuk Mengurangi Bullying pada Siswa Anak Usia Dini Rezza Amalia, Benny Hendriana, Amelia Vinayastri

DOI: https://doi.org/10.31004/edukatif.v3i5.869

\section{PENDAHULUAN}

Penyelenggaraan pendidikan anak usia dini bertujuan sebagai pembinaan, pengembangan dan menumbuhkan seluruh potensi pada diri anak dengan maksimal, sehingga dapat terbentuk perilaku dan kemampuan yang sesuai dengan tahap perkembangan anak (Mundia Sari \& Setiawan, 2020). Perkembangan merupakan penyatuan dari aspek nilai agama dan moral, fisik-motorik, kognitif, bahasa, sosial-emosional, dan seni (PERMENDIKBUD, 2014). Pada dasarnya mayoritas kegiatan untuk anak usia dini adalah bermain, baik bermain bersama dengan temannya ataupun bermain sendiri. Pada kegiatan bermain bersama ini berhubungan dengan salah satu aspek perkembangan anak yaitu sosial-emosional karena pada saat anak bermain bersama akan terjadi interaksi sosial. Perkembangan sosial-emosial pada anak berkaitan pada kemampuan anak dalam berinteraksi dengan orang lain disekitarnya, kemampuan untuk menyesuaikan diri dengan lingkungan sekitarnya, dan dapat mengendalikan diri (Abubakar, 2018; Khasanah, 2013)

National Association for the Education Young Children (NAEYC) menyatakan bahwa anak usia dini merupakan anak yang berada pada usia 0 sampai 8 tahun (Patmonodewo, 2000). Di Indonesia anak dalam rentan usia tersebut memerlukan perhatian yang khusus untuk bersosialisasi lebih luas karena masih mengalami berbagai transisi dari lingkungan dan cara belajarnya, jika anak belum dapat bersosialisasi dengan baik dengan teman ataupun lingkungannya maka anak akan berpotensi menjadi korban bullying (Elmahera, 2018; Siregar, 2016). Bullying adalah sebuah bentuk penindasan atau kekerasan yang dilakukan berulangulang kali oleh individu atau sekelompok orang dengan tujuan menyakiti seseorang yang lebih lemah sehingga membuat dampak cukup serius bagi korbannya (Anwar \& Karneli, 2020; Campaign, 2015; Puji Susilo, n.d.). Fenomena bullying yang terjadi disekitar anak sudah bukan lagi hal yang baru, namun penangannya sampai saat ini juga masih belum maksimal, pada sudah sangat jelas bullying memberikan dampak yang negative untuk anak usia dini, baik korbannya maupun pelaku tindak bullying (Arumsari \& Setyawan, 2019; Tirmidziani et al., 2018; Wahyuni \& Pransiska, 2019)

Ada beberapa jenis katagori bullying yang sering terjadi, yaitu : (1) Bullying fisik, merupakan salah satu jenis bullying yang tidak terlihat secara kasat mata, siapapun bisa melihat karena terjadi kontak fisik berupa memukul, mendorong, dan menendang, (2) Bullying verbal, merupakan jenis bullying yang dapat dideteksi seseorang melalui indra pendengaran berupa mengejek, memfitnah, dan menghina, (3) Bullying psikologis, merupakan jenis bullying yang paling berbahaya karena dapat menyerang mental bagi korban dan tidak mudah untuk tertdeteksi oleh mata maupun telinga, berupa mempermalukan, mengucilkan, dan mengabaikan, (4) Cyberbullying, merupakam jenis bullying yang dilakukan secara sengaja dalam bentuk ancaman, intimidasi, dan pelecehan yang dilakukan melalui perantara media elektronik baik di internet atuapun telepon (Azzahra et al., 2021; Denanda \& Rismaningtyas, 2021; SEJIWA, 2021; Susan Kezia Valerrie Siahaya, Harly Stanly Muaja, 2021).

Dari hasil riset Programme for International Students Assesment (PISA) menunjukkan bahwa di Indonesia siswa yang mengalami bullying sebanyak $41 \%$. Angka tersebut jauh diatas rata-rata dari negara anggota OECD sebesar 22,7\%. Hal ini menempatkan Indonesia pada urutan tertinggi kelima dari 78 negara sebagai negara dengan siswa paling banyak mengalami bullying. Siswa-siswa di Indonesia juga telah mengalami tindak intimidasi sebanyak $15 \%$, pengancaman $14 \%$, dikucilkan ,19\%, dihina dan diambil baranya sebanyak 22\%, di dorong oleh teman 18\% dan berita buruknya disebar 20\% (Jayani, 2019). Dari data hasil penelitian tersebut dapat dilihat bahwa siswa yang mengalami tindak penghinaan dan dirampas barangnya menjadi yang paling tinggi dengan presentase $22 \%$, tindakan ini termasuk kedalam bullying jenis verbal.

Penulis melakukan pengamatan kondisi pembelajaran peserta didik di PAUD Anggrek Tanjung Barat, Jakarta Selatan peneliti menemukan sebuah kasus bullying jenis verbal dan psikologi yang masih terjadi pada anak-anak seperti mengejek temannya bahkan menjauhi temannya yang terlihat lebih lemah atau memiliki kekurangan. Namun sangat disayangkan karena beberapa guru masih mengganggap bullying ini bukan lah 
2394 Pengembangan Media Komik Elektronik untuk Mengurangi Bullying pada Siswa Anak Usia Dini Rezza Amalia, Benny Hendriana, Amelia Vinayastri

DOI: https://doi.org/10.31004/edukatif.v3i5.869

masalah yang serius, guru hanya mengingatkan kepada anak untuk saling menyayangi. Penyampaian guru saat mengingatkan anak untuk saling menyayangi juga hanya menggunakan media seadanya dengan banyak memberi ceramah sehingga menimbulkan kebosanan. Hal inilah yang menjadi faktor penyebab kasus bullying masih terus terjadi di dunia anak terutama pada PAUD Anggrek Tanjung Barat, maka dari itu sekolah membutuhkan media pembeljaran yang menarik, kreatif, dan inovatif agar anak termotivasi dalam belajar. Penggunaan komik elektronik dapat membantu anak untuk mengembangkan imajinasi, berfikir kreatif, dan inovatif serta juga dapat meningkatkan minat membaca anak sedari dini. Melalui komik elektronik ini orang tua dan guru dapat menjadikan media ini sebagai salah satu wadah tekologi untuk bekerjasama mendidik dan meningkatkan pemahaman konsep anak tentang edukasi bullying yang dapat terjadi di sekitar anak.

Media komik elektronik merupakan salah satu media pembelajaran yang sangat menyenangkan untuk anak usia dini dikarenakan mereka masih pada tahap bermain, gambaran dalam komik dapat menghidupkan deretan teks cerita sehingga dapat dengan mudah menyampaikan pesan kepada anak dengan tetap mengutamakan prinsip belajar melalui bermain kepada anak (Handayani \& Koeswanti, 2020; Indriasih et al., 2020; Ruiyat et al., 2019). Media komik elektronik menjadi salah satu cara meningkatkan kualitas pendidikan anak usia dini, karena didalam komik banyak menampilkan gambar-gambar yang bersifat informasi sehingga mengurangi kelelahan pada mata anak karena jumlah tulisan yang sedikit, media ini juga sangat efektif dalam proses belajar mengajar karena dapat menciptakan serta meningkatkan minat belajar dan menimbulkan minat apresiasi anak (Faisal et al., 2017; Syarah et al., 2018).

Komik elektronik berasal dari kata komik merupakan sebuah media pembelajaran berjenis multimedia yang memiliki kelebihan mobilitas yang tinggi. Disajikan dalam bentuk imaji-imaji gambar dan balon-balon teks sederhana yang disusun membentuk sebuah cerita untuk menyampaikan informasi secara popular dan mudah di mengerti, kemudian diterbitkan secara online (Ruiyat et al., 2019; Sudjana dan Rivai, 2017; Sung \& Putra, 2018; Syarah et al., 2018; Wicaksana et al., 2019). Komik elektronik yang dimaknai sebagai gambar kartun berteks memiliki kemampuan menyampaikan pesan dengan gaya yang ringan dan menyenangkan, melalui karakter dalam komik elektronik dapat merangsang motivasi anak untuk belajar dan meningkatkan karakter anak usia dini sehingga akan berhasil untuk pendidikan lanjut (Adeliyanti et al., 2018; Aeni \& Yusupa, 2018). Pengembangan e-comic juga dapat meningkatkan pemahaman konservasi kelautan anak usia dini (Syarah et al., 2018). Komik elektonik juga dapat dikembangkan untuk meningkatkan kecakapan hidup anak usia dini (Indriasih et al., 2020). Berdasarkan hasil penelitian terdahulu peneliti belum menemukan adanya pengembangan media komik elektronik yang digunakan untuk edukasi bullying pada anak usia dini, maka dari itu peneliti memiliki keyakinan untuk mengembangkan sebuah media edukasi berupa komik elektronik untuk anak usia dini yang dapat diakses dengan mudah dan penggunaan yang praktis untuk guru dan orang tua dalam memberikan pemahaman kepada anak tentang bahayanya bullying.

\section{METODE PENELITIAN}

Jenis metode pada penelitian ini adalah pengembangan Research and Development (R\&D) dengan model pengembangan ADDIE. Model penelitian ADDIE dipilih dalam penelitian ini berdasarkan atas pertimbangan bahwa model ini disusun secara sederhana dan terstruktur dengan sistematis membuat model desain ini mudah dipahami dan diaplikasikan sehingga dirasa akan lebih efektif, dinamis, dan mendukung penelitian pengembangan yang dilakukan oleh peneliti (Pratiwi et al., 2021). Langkah dalam model pengembangan ADDIE yaitu terdiri dari analisis (analysis), desain (design), pengembangan (development), implementasi (implementation), dan evaluasi (evaluation) (Nasrulloh et al., 2020). Penelitian ini dilaksanakan di PAUD Anggrek Tanjung Barat, Jakarta Selatan dengan subjek penelitian yaitu anak berusia 5-6 tahun. Teknik pengumpulan data pada penelitian ini menggunakan teknik pengumpulan data non tes. Teknik non tes yang digunakan berupa angket yang diisi oleh guru. Teknik analisis data yang digunakan dalam penelitian ini 
2395 Pengembangan Media Komik Elektronik untuk Mengurangi Bullying pada Siswa Anak Usia Dini Rezza Amalia, Benny Hendriana, Amelia Vinayastri

DOI: https://doi.org/10.31004/edukatif.v3i5.869

menggunakan teknik analisis statistik deskriptif dalam bentuk deskriptif presentase. Tahap-tahap dalam model pengembangan $A D D I E$ adalah sebagai berikut ini.

\section{Analisis (analysis)}

Tahapan analisis (analysis) merupakan pelaksanaan kegiatan observasi situasi lapangan dan lingkungan sehingga dapat peneliti dapan mengidentifikasi beberapa kebutuhan untuk memunculkan masalah dasar yang dihadapi dalam kasus bullying sehingga dapat ditemukan media pembelajaran apa yang dapat dikembangkan oleh peneliti sesuai dengan kebutuhan.

\section{Desain (design)}

Tahap desain (design) merupakan tindak lanjut dari tahapan analisis, peneliti akan mulai merancang dan mengembangkan media pembelajaran komik dari hasil analisis yang sudah didapatkan pada tahap sebelumnya.

\section{Pengembangan (development)}

Tahap pengembangan merupakan proses pembuatan media berdasarkan desain yang sudah peneliti rancang, lalu menentukan output penyajian media untuk tahap validasi oleh para ahli dan diuji cobakan kepada guru dan orang tua murid PAUD Anggrek Tanjung Barat.

\section{Implementasi (implementation)}

Tahap implementasi dilakukan untuk melakukan validasi dan uji cobakan kepada pengguna, yaitu anak, orang tua, dan pendidik. Penguji validasi akan diberika instrument penilaian, lalu guru dan orang tua akan diberikan angket penilaian yang sudah disusun. Jika pada tahap uji coba yang dilakukan mendapatkan tanggapan yang baik maka produk sudah dapat dikatakan layak untul digunakan. Tetapi masukan komentar pada tahap ini dapat menjadi perimbangan dilakukannya revisi pada media komik elektronik sehingga produk yang dihasilkan lebih baik lagi. Selanjutnya jika kuesioner untuk ahli media, ahli materi, ahli bahasa, guru, dan orang tua kelompok B sudah siap maka selanjutnya masing-masing ahli akan memberika penilaian menggunakan penilaian dengan kriteria penilaian angket pada tabel 1 .

Tabel 1

Kriteria Penilaian Angket

\begin{tabular}{cc}
\hline Jawaban & Score \\
\hline Sangat Baik & 4 \\
\hline Baik & 3 \\
\hline Kurang Baik & 2 \\
\hline Sangat Kurang Baik & 1 \\
\hline
\end{tabular}

Hasil presentase score rata-rata yang diperoleh dari masing-masing ahli, guru dan orang tua kelompok B kemudia dirata-ratakan kembali untuk mendapat nilai yang dapat mewakili responden, dapat dilakukan dengan cara menjumlah keseluruhan nilai dari responden kemudia membaginya dengan jumlah responden. pengambilan keputusan yang digunakan dalam penelitian ini menggunakan konversi tingkat pencapain dengan indikator skore kuesioner pada tabel 2.

Tabel 2

Kriteria Tingkat Validitas

\begin{tabular}{cc}
\hline Presentase & Kategori \\
\hline $100 \%-86 \%$ & Sangat Valid \\
\hline $85 \%-71 \%$ & Valid \\
\hline $70 \%-65 \%$ & Cukup Valid \\
\hline$<55 \%$ & Kurang Valid \\
\hline
\end{tabular}


2396 Pengembangan Media Komik Elektronik untuk Mengurangi Bullying pada Siswa Anak Usia Dini Rezza Amalia, Benny Hendriana, Amelia Vinayastri

DOI: https://doi.org/10.31004/edukatif.v3i5.869

Apabila presentase nilai dari validator kuesioner memenuhi kualifikasi baik/layak. maka tahap yang terakhir merupakan tahap evaluasi.

\section{Evaluasi (evaluation)}

Pada bagian tahap evaluasi produk dinilai keseluruhan untuk dapat mengetahui nilai akhir produk yang dikembangkan. kemudia berkaitan dengan kekurangan yang ada pada produk nantinya akan direvisi sampai memenuhi kriteria kelayakan berdasarkan masukan dari ahli sampai media buku komik elektronik edukasi bullying pada anak siap untuk disebarkan pada masyarakat.

\section{HASIL DAN PEMBAHASAN PENELITIAN}

Penelitian ini menghasilkan sebuah produk media komik elektronik yang berfungsi sebagai alat edukasi bullying anak usia dini, khususnya pada anak kelompok B di PAUD Anggrek Tanjung Barat. Pengembangan media edukasi komik elektronik ini juga merupakan alat permainan edukatif (APE) yang dapat mempermudah guru menyampaikan pembelajaran tentang bullying dilingkungan anak. Proses pembuatan dilakukan sesuai dengan alur model pengembangan $A D D I E$, proses pembuatan komik elektornik edukasi bullying adalah sebagai berikut:

\section{Analisis (analysis)}

Pada tahap awal dalam penelitian ini adalah melakukan observasi untuk mengumpulkan informasi, pengumpulan informasi pada tahap ini dilakukan dengan cara observasi langsung pada PAUD Anggrek Tanjung Barat. Tujuan diilakukannya observasi ini sebagai acuan untuk membuat suatu produk media pembelajaran yang sesuai dengan kebutuhan di PAUD Anggrek Tanjung Barat, dari hasil analisis yang dilakukan peneliti akan mengembangkan sebuah produk media pembelajaran berupa komik elektronik untuk edukasi bullying anak usia dini pada kelompok B PAUD Anggrek Tanjung Barat.

\section{Desain (design)}

Pada tahap desain, peneliti mulai membuat skenario untuk komik elektronik, skenario yang dirancang terdiri dari ide dasar, alur cerita, konflik, karakter tokoh, latar belakang dan tempat. Skenario dibuat berdasarkan dari kegiatan sehari-hari anak disekolah bersama teman-temannya dan guru, alur cerita dibuat dengan sederhana namun tetap dapat menyampaikan informasi mengenai bullying kepada anak. Setelah skenario selesai dibuat peneliti mulai mencari judul untuk komik, lalu dilanjutkan dengan penyusunan storyboard untuk menyalurkan ide cerita dalam bentuk gambar kasar untuk menvisualisasikan adegan dalam skenario.

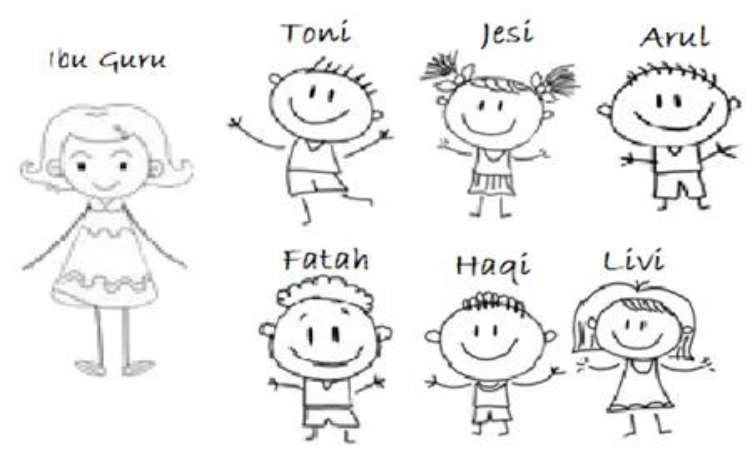

Gambar 1. Storyboard Tokoh Komik Elektronik 
2397 Pengembangan Media Komik Elektronik untuk Mengurangi Bullying pada Siswa Anak Usia Dini Rezza Amalia, Benny Hendriana, Amelia Vinayastri

DOI: https://doi.org/10.31004/edukatif.v3i5.869

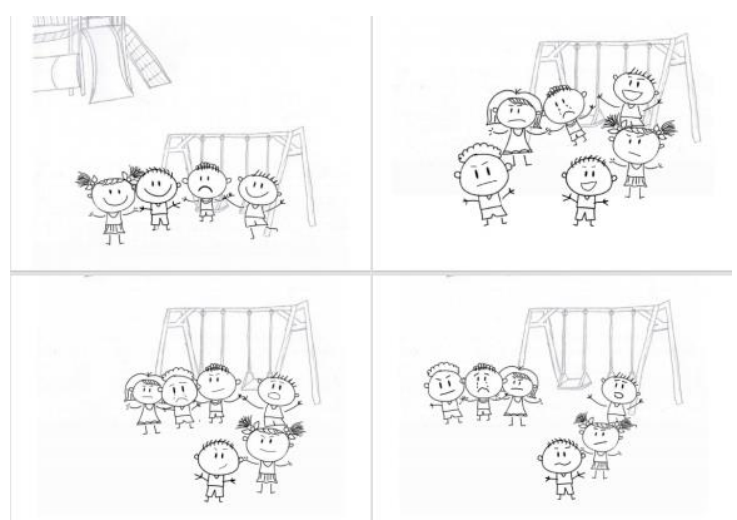

Gambar 2. Storyboard Alur Cerita Komik

\section{Pengembangan (development)}

Tahap ketiga ini merupakan tahap mengembangkan produk, setelah membuat desain komik peneliti lanjut pada proses pembuatan sketsa untuk menerjemahkan storyboard agar detail terlihat lebih jelas, proses pembuatan sketsa ini dilakukan secara digital menggunakan software MediBang Paint. Setelah pembuatan sketsa selesai kemudia dilanjut pada proses mewarnai komik, karena proses mewarnai dan pemiliham warna merupakan tahapan yang sangat penting untuk menarik minat anak terhadap komik, proses mewarnai komik juga dilakukan secara digital dengan menggunakan software yang sama dengan proses pembuatan sketsa. Lalu proses yang terakhir adalah menentukan output peniliti menampilkan komik secara online atau disimpan dengan format PDF (Portable Document Format).

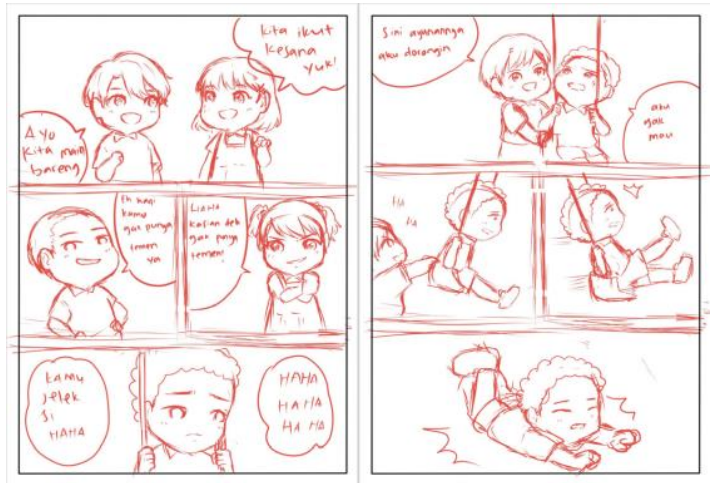

Gambar 3. Proses Pembuatan Sketsa

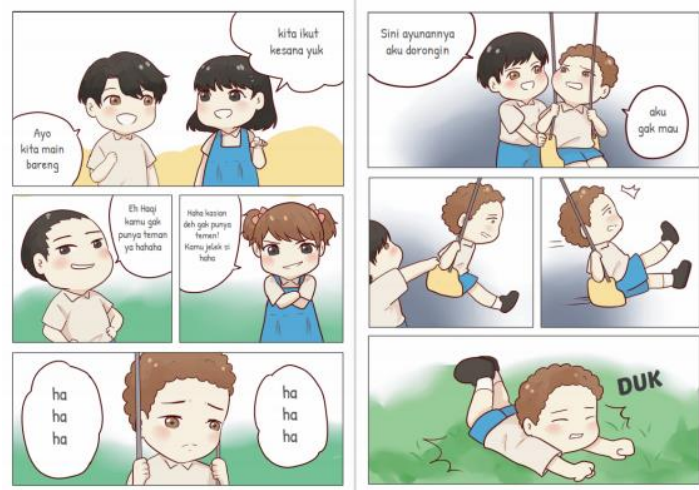

Gambar 4. Proses Mewarnai Komik 
2398 Pengembangan Media Komik Elektronik untuk Mengurangi Bullying pada Siswa Anak Usia Dini Rezza Amalia, Benny Hendriana, Amelia Vinayastri

DOI: https://doi.org/10.31004/edukatif.v3i5.869

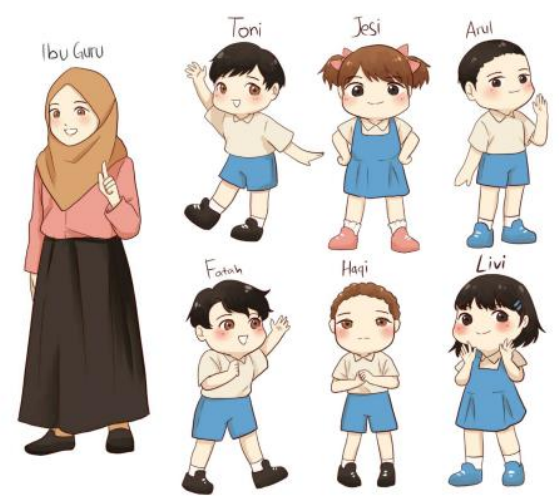

Gambar 5. Tokoh Karakter Komik

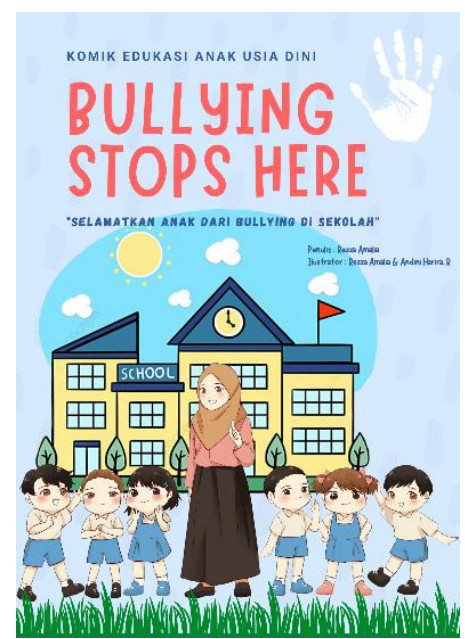

Gambar 6. Sampul Komik Elektronik

\section{Implementasi (implementation)}

Selanjutnya pada tahap implementasi peneliti melakukan diuji coba oleh validator ahli media, ahli materi, ahli bahasa, guru PAUD Anggrek Tanjung Barat, dan orang tua murid kelompok B, maka hasil yang didapat dari masing-masing validator dapat dijabarkan dalam tabel hasil uji kelayakan media pembelajaran dapat dilihat pada Tabel 3.

Tabel 3

Uji Kelayakan Media Pembelajaran

\begin{tabular}{ccc}
\hline Responden & Presentasi & Keterangan \\
\hline Ahli Media & $85 \%$ & Valid \\
\hline Ahli Materi & $95 \%$ & Sangat Valid \\
\hline Ahli Bahasa & $75 \%$ & Valid \\
\hline Guru PAUD Anggrek & $89 \%$ & Sangat Valid \\
\hline Orang Tua Kelompok B & $93 \%$ & Sangat Valid \\
\hline
\end{tabular}

Hasil validasi dari ahli media mengenai penyajian komik elektronik dan tampilan menyeluruh dalam komik. Dari hasil yang diperoleh validator ahli media mendapatkan presentase $85 \%$ dan valid digunakan untuk media pembelajaran anak usia dini. Selanjutnya yaitu ahli validasi dari ahli materi megenai kesesuaian cerita komik, manfaat media bagi anak, dan manfaat media untuk kegiatan pendidikan. Maka, dengan menggunakan kuesionar sebagai alat ukur pengambangan media pembelajaran komik elektronik dapat divalidasi oleh ahli materi. Jadi berdasarkan hasil presente yang didapat $91 \%$ dan sangat valid untuk digunakan pada pembelajaran anak usia dini. 
2399 Pengembangan Media Komik Elektronik untuk Mengurangi Bullying pada Siswa Anak Usia Dini Rezza Amalia, Benny Hendriana, Amelia Vinayastri

DOI: https://doi.org/10.31004/edukatif.v3i5.869

Hasil validasi selanjutnya yaitu ahli bahasa yang berisi tetang kesesuaian bahasa yang digunakan dalam komik mudah untuk dipahami anak usia dini, tata bahasa dalam komik dan ejaan yang gunakan EYD. Dari hasil perolehan penilaian validator ahli bahasa memperoleh hasil presentase sebesar $75 \%$ dan valid digunakan untuk media pembelajaran anak usia dini. Selanjutnya hasil validasi yang dilakukan oleh guru PAUD Anggrek Tanjung Barat, dengan menggunakan kuesioner berdasarkan hasil uji coba yang dilakukan oleh guru yang mengenai isi materi yang dapat disampaikan dari komik, media pembelajaran mudah digunakan dalam pembelajaran, dan manfaat media untuk kegiatan belajar mengajar. Dilihat dari hasil kuesioner dari guru diPAUD Anggrek mendapat nilai dengan presentase $89 \%$ yang termasuk dalam kualifikasi sangat valid. Dan selanjutnya hasil validasi terakhir yang dilakukan oleh orang tua kelompok B PAUD Anggrek mengenai penyajian komik dapat menarik anak, cerita yang tersaji mudah dipahami anak, dan dapat menambah pemahaman anak tentang bullying. Dan dari hasil kuesioner orang tua kelompok B mendapat nilai presentase 93\% yang termasuk dalam kualifikasi sangat layak.

\section{Evaluasi (evaluation)}

Tahapan yang terakhir adalah evaluasi media pembelajaran komik elektronik edukasi bullyingin, tahapini merupakan tahapan untuk menganalisis kevalidan dan kelayakan serta mengetahu kelebihan dan kekurangan dari produk yang telah dikembangkan. Beradasarkan hasil penelitian pengembangan media komik elektronik edukasi bullying ini dapat dinyatakan layak, namun pada saat uji coba terhadap orang tua terdapat masukan untuk mengubah judul agar lebih mudah dipahami oleh orang tua, maka peneliti mengubah judul yang semulanya menggunakan full berbahasa Inggris menjadi seperti pada (Gambar 6: Sampul Komik Elektronik).

Berdasarkan dari hasil analisis validitas, dan uji coba media komik elektronik layak untuk digunkan sebagai bahan ajar pengenalan bullying pada anak usia dini. Sejalan dengan penelitian yang telah dilakukan oleh (Syarah et al., 2018) menghasilkan pengembangan media komik elektronik yang layak digunakan untuk anak usia dini dapat meningkatkan pemahaman anak usia dini dan penggunaannya dapat menjadi solusi permasalahan penggunaan gadget oleh orang tua dirumah. Di tambah dengan penelitian yang dilakukan oleh (Indriasih et al., 2020) menghasilkan pengembangan media komik elektronik yang layak digunakan mampu untuk meningkatkan motivasi dan minat siswa dalam belajar tentang kecakapan hidup, membantu mengaktifkan siswa secara fisik dan emosi, serta mempermudah siswa dalam belajar. Dengan demikian dapat dikatakan bahwa mengembangkan media komik elektronik dapat mengajarkan kepada anak tentang bahaya bullying sehingga dapat mencegah terjadinya kasus bullying pada anak usia dini dan mengurangi angka terjadinya tindak bullying.

\section{KESIMPULAN}

Berdasarkan dari hasil penelitian yang telah dilaksanakan dapat disimpulkan bahwa media pembelajaran komik elektronik sangat valid untuk digunakan sebagai bahan pembelajaran siswa anak usia dini. Hal ini terlihat dari hasil validasi oleh para ahli mendapatkan rata-rata sebesar $83.67 \%$ dengan kategori valid dan uji coba terhadap guru dan orang tua kelompok B PAUD Anggrek Tanjung Barat mendapatkan rata-rata sebesar 91\% dengan kategori sangat valid. Maka dengan demikian media pembelajaran komik elektronik dapat dinyatakan layak untuk digunakan.

Dari hasil penelitian pengembangan media komik elektroni dapat disimpulkan bahwa media dinyatakan valid atau layak digunakan berdasarkan hasil penilaian dari validasi ahli dan uji coba. Kegunaan komik elektronik memberikan dampak positif, banyak manfaat yang dapat diperoleh dari media pembelajaran komik elektronik baik bagi anak usia dini, guru, maupun orang tua. Dengan demikian disarankan bagi guru untuk melakukan inovasi dalam mengembangkan media pembelajaran untuk anak dengan penggunaan teknologi. 
2400 Pengembangan Media Komik Elektronik untuk Mengurangi Bullying pada Siswa Anak Usia Dini Rezza Amalia, Benny Hendriana, Amelia Vinayastri

DOI: https://doi.org/10.31004/edukatif.v3i5.869

\section{DAFTAR PUSTAKA}

Adeliyanti, S., Suharto, \& Hobri. (2018). Pengembangan E-Comic Matematika Berbasis Teknologi Sebagai Suplemen Pembelajaran Pada Aplikasi Fungsi Kuadrat. Kadikma, 9(1), 123-130.

Aeni, W. A., \& Yusupa, A. (2018). Model Media Pembelajaran E-Komik Untuk SMA. Jurnal Kwangsan, 6(1), 1. https://doi.org/10.31800/jurnalkwangsan.v6i1.66

Ambarini, R., Indrariani, E., \& Zahraini, A. (2018). Antisipasi Pencegahan Bullying Sedini Mungkin: Program Anti Bullying Terintegrasi Untuk Anak Usia Dini. Journal of Dedicators Community, 2(2), 64-82. https://doi.org/10.34001/jdc.v2i2.587

Anwar, K., \& Karneli, Y. (2020). The Relationship between Bullying Behavior and Students ' Social Interaction Ability. Jurnal Neo Konseling, 2(4), 1-7. https://doi.org/10.24036/00302kons2020

Azzahra, S. S., Pandin, M. A., Glorino, M., \& Pandin, R. (2021). The factors of bullying and character education on teenagers. April, 1-9. https://doi.org/10.20944/preprints202104.0102.v1

Campaign, S. D. S. B. (2015). Buku Panduan Melawan Bullying.

Denanda, N. P., \& Rismaningtyas, F. (2021). Praktik Sosial Cyber Bullying Dalam Jaringan. Jurnal Analisa Sosiologi, 10. https://doi.org/10.20961/jas.v10i0.47641

Elmahera, D. (2018). Analisis Bullying Pada Anak Usia Dini. Prosiding Seminar Dan Diskusi Nasional Pendidikan Dasar.

Faisal, Baskoro, G. W., Ridwan, M., \& Mardawati. (2017). Peningkatan kualitas pendidikan anak dengan pembangunan komik elektronik. Ikraith-Informatika, 1(2), 24-29.

Handayani, P., \& Koeswanti, H. D. (2020). Pengembangan Media Pembelajaran Buku Cerita Bergambar Untuk Meningkatkan Minat Membaca Siswa Sekolah Dasar. Jurnal Basicedu, 4(4), 994-1003. https://doi.org/10.31004/basicedu.v4i4.492

Indriasih, A., Sumaji, S., Badjuri, B., \& Santoso, S. (2020). Pengembangan E-Comic Sebagai Media Pembelajaran Untuk Meningkatkan Kecakapan Hidup Anak Usia Dini. Refleksi Edukatika: Jurnal Ilmiah Kependidikan, 10(2), 154-162. https://doi.org/10.24176/re.v10i2.4228

Jayani, D. H. (2019). PISA : Murid Korban 'Bully' di Indonesia Tertinggi Kelima di Dunia. In Databoks (p. 2019).

http://databoks.katadata.co.id/datapublish/2019/12/12/pisa-murid-korban-bully-di-indonesia-tertinggikelima-di-dunia

Nasrulloh, M. F., Hanik, S., \& Satiti, W. S. (2020). E-Comic Learning Media Based Problem Based Learning In Subject of Linear Equation System. Hipotenusa: Journal of Mathematical Society, 2(1), 34-40. https://doi.org/10.18326/hipotenusa.v2i1.34-40

Patmonodewo, S. (2000). Pendidikan anak prasekolah. In Pedagogik : Jurnal Pendidikan (Issue pendidikan pra sekolah, p. 33). http://library.walisongo.ac.id/digilib/files/disk1/9/jtptiain-gdl-s1-2005-sitifaidah-403Bab2_310-4.pdf

Pratiwi, S. I., Dasar, S., Kristen, U., \& Wacana, S. (2021). Pengembangan Bahan Ajar Tematik Berbasis Website untuk Peserta Didik di Sekolah Dasar Abstrak. EDUKATIF: Jurnal Ilmu Pendidikan, 3(2), 333-340.

Puji Susilo, D. S. (n.d.). Studi Tentang Perilaku Bullying Verbal Dan Penanganannya Pada Siswa Kelas Xi Sma I Al-Aly Kelitidu Bojonegoro. 54-63.

Ruiyat, S. A., Yufiarti, Y., \& Karnadi, K. (2019). Peningkatan Keterampilan Berbicara dengan Bercerita Menggunakan Komik Elektronik Tematik. Jurnal Obsesi : Jurnal Pendidikan Anak Usia Dini, 3(2), 518. https://doi.org/10.31004/obsesi.v3i2.256

Sejiwa. (2021). Bullying A-Z. http://sejiwa.org/bullying-researches/ 
2401 Pengembangan Media Komik Elektronik untuk Mengurangi Bullying pada Siswa Anak Usia Dini Rezza Amalia, Benny Hendriana, Amelia Vinayastri

DOI: https://doi.org/10.31004/edukatif.v3i5.869

Siregar, J. (2016). Gambaran Perilaku Bullying pada Masa Kanak-Kanak Akhir di Kota Medan. An - Nafs, 10(01), 1-11.

Sudjana dan Rivai, 2007. (2017). Efektivitas Media Pembelajaran E-Comic. Edudeena, 1, 1-8.

Sung, M. K., \& Putra, R. W. (2018). Pengembangan Media Interaktif Komik Elektronik Sebagai Media Edukasi Pada Sdn Gandaria Utara 08 Pagi , Jakarta Selatan. Jurnal IDEALIS, 1(4), 397-403.

Susan Kezia Valerrie Siahaya, Harly Stanly Muaja, C. M. N. (2021). Penegakan Hukum Terhadap Pelaku Penindasan atau Bullying Disekolah. Lex Crimen, X(3), 236-246.

Syarah, E. S., Yetti, E., \& Fridani, L. (2018). Pengembangan Media Komik Elektronik Untuk Meningkatkan Pemahaman Konservasi Anak Usia Dini. JPUD - Jurnal Pendidikan Usia Dini, 12(2), 231-240. https://doi.org/10.21009/jpud.122.04

Tirmidziani, A., Farida, N. S., Lestari, R. F., Trianita, R., Khoerunnisa, S., \& Khomaeny, E. F. F. (2018). Upaya Menghindari Bullying pada Anak Usia Dini. Jurnal Pendidikan: Early Chilhood, 2(1), 1-8.

Wicaksana, I. P. G. C. R., Agung, A. A. G., \& Jampel, I. N. (2019). Pengembangan E-Komik Dengan Model Addie Untuk Meningkatkan Minat Belajar Tentang Perjuangan Persiapan Kemerdekaan Indonesia. Jurnal EDUTECH Universitas Pendidikan Ganesha, 7(2), 48-59.

https://ejournal.undiksha.ac.id/index.php/JEU/article/view/23159 